\title{
Unusual Coordination Mode of Thiosemicarbazone Ligands. A Search for the Origin
}

\author{
Falguni Basuli, ${ }^{1 \mathrm{a}}$ Shie-Ming Peng, ${ }^{\text {lb }}$ and Samaresh Bhattacharya ${ }^{*, 1 a}$ \\ Department of Chemistry, Inorganic Chemistry Section, Jadavpur University, Calcutta 700 032, India, \\ and Department of Chemistry, National Taiwan University, Taipei, Taiwan, ROC
}

Received September 10, 1999

\begin{abstract}
Twelve mixed-ligand thiosemicarbazone complexes of ruthenium and osmium, ten of general formula $\left[\mathrm{M}(\mathrm{bpy})_{2^{-}}\right.$ (bztsc-R) $\mathrm{ClO}_{4},(\mathrm{M}=\mathrm{Ru}, \mathrm{Os}$; bpy = 2,2'-bipyridine, Hbztsc- $\mathrm{R}=$ benzaldehyde thiosemicacbazone $)$ and two of type $\left[\mathrm{M}(\mathrm{bpy})_{2}(\mathrm{actsc})\right] \mathrm{ClO}_{4}$ (Hactsc $=$ acetonethiosemicarbazone), have been synthesized and characterized. All the complexes are diamagnetic (low-spin $\mathrm{d}^{6}, S=0$ ) and in acetonitrile solution show several intense metalto-ligand charge-transfer (MLCT) transitions in the visible region. Structures of Hbztsc-OMe, $\left[\mathrm{Ru}(\mathrm{bpy})_{2}(\mathrm{bztsc}-\right.$ $\left.\left.\mathrm{NO}_{2}\right)\right] \mathrm{ClO}_{4}$ and $\left[\mathrm{Ru}(\text { bpy })_{2}(\right.$ actsc $\left.)\right] \mathrm{ClO}_{4}$ have been determined by X-ray crystallography. Benzaldehyde thiosemicarbazone exists in the thione form with the phenyl group trans to the hydrazinic nitrogen. The benzaldehyde thiosemicarbazone ligand coordinates to the metals through the hydrazinic nitrogen and sulfur with a bite angle of $\sim 67^{\circ}$, forming a four-membered chelate ring. However, the actsc ligand coordinates through the imine nitrogen and sulfur, forming a five-membered chelate ring with a bite angle of $\sim 81^{\circ}$. The difference in coordination modes of two types of thiosemicarbazone ligands, viz., bztsc-R and actsc, appears to result from the difference in steric bulk of the aryl and methyl group trans to the hydrazinic nitrogen. In acetronitrile solution they all show a reversible metal(II) - metal(III) oxidation in the range $0.18-0.58 \mathrm{~V}$ vs SCE followed by an irreversible oxidation in the range 1.11-1.60 V vs SCE. Two successive one-electron reductions of the coordinated bipyridine are also observed in the range -1.53 to $-1.96 \mathrm{~V}$ vs SCE.
\end{abstract}

\section{Introduction}

In a recent publication, ${ }^{2}$ we reported the unusual coordination mode (1) of salicylaldehyde thiosemicarbazone (Hsaltsc) observed in complexes of type $\left[\mathrm{M}\left(\mathrm{PPh}_{3}\right)_{2}(\mathrm{saltsc})_{2}\right]$ where $\mathrm{M}=$ $\mathrm{Ru}$, Os. Two factors appeared to be probable for such a

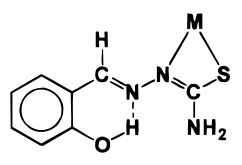

1

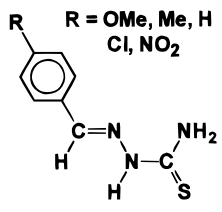

2

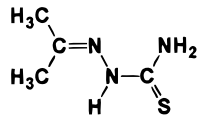

3 coordination mode: (a) intramolecular hydrogen bonding between the phenolic hydrogen and the imine nitrogen, which reduces availability of lone pair on the imine nitrogen and thus prevents coordination from it, and (b) steric hindrance created by the bulky $\mathrm{PPh}_{3}$ ligands. Later we have observed that mere prevention of the possibility of intramolecular hydrogen bonding in the thiosemicarbazone ligand cannot change the coordination mode. $^{3}$ In the present work, which has emerged from our continued search for the actual reason behind this unusual coordination mode and which again involves mixed-ligand thiosemicarbazone complexes of ruthenium and osmium, both the thiosemicarbazone ligand has been modified and the coligand has been changed. The hydroxy group of salicylaldehyde thiosemicarbazone has been removed to prevent intramolecular hydrogen bonding, and thiosemicarbazones of para-substituted

(1) (a) Jadavpur University. (b) National Taiwan University.

(2) Basuli, F.; Peng, S. M.; Bhattacharya, S. Inorg. Chem. 1997, 36, 5645.

(3) Basuli, F.; Ruf, M.; Pierpont, C. G.; Bhattacharya, S. Inorg. Chem. 1998, 37, 6113 . benzaldehydes (Hbztsc-R, 2) have been used. Thiosemicarbazone of acetone (Hactsc, $\mathbf{3}$ ) has also been used to reduce steric bulk of the thiosemicarbazone ligand. The thiosemicarbazone ligands are abbreviated in general as Htsc, where $\mathrm{H}$ stands for the dissociable proton. Instead of triphenylphosphine, less bulky $2,2^{\prime}$-bipyridine (bpy) has been used as the coligand. The effect of all these modifications on the coordination mode of the thiosemicarbazone ligands, as observed in a family of complexes of type $\left[\mathrm{M}(\mathrm{bpy})_{2}(\mathrm{tsc})\right]^{+}(\mathrm{M}=\mathrm{Ru}, \mathrm{Os})$, is described in this paper.

\section{Experimental Section}

Materials. Commercial ruthenium trichloride and osmium tetroxide were purchased respectively from Arora Matthey, Calcutta, India and Johnson Matthey, U.K. Commercial ruthenium trichloride was converted to $\mathrm{RuCl}_{3} \cdot 3 \mathrm{H}_{2} \mathrm{O}$ by repeated evaporation with concentrated hydrochloric acid. Osmium tetroxide was converted to $\left[\mathrm{NH}_{4}\right]_{2}\left[\mathrm{OsBr}_{6}\right]$ by reduction with hydrobromic acid. 2,2'-Bipyridine (bpy) was purchased from Loba Chemie, Mumbai, India. $\left[\mathrm{Ru}(\mathrm{bpy})_{2} \mathrm{Cl}_{2}\right]$ and [Os(bpy $\left.)_{2} \mathrm{Br}_{2}\right]$ were prepared by following reported procedures. ${ }^{4,5}$ The thiosemicarbazone ligands were prepared by reacting equimolar amounts of thiosemicarbazide and the respective para-substituted benzaldehyde or acetone in a 1:1 ethanol-water mixture. Purification of acetonitrile and preparation of tetraethylammonium perchlorate (TEAP) for electrochemical work were performed as before. ${ }^{2}$

Preparations of Complexes. All the $\left[\mathrm{Ru}(\mathrm{bpy})_{2}(\mathrm{tsc}) \mathrm{ClO}_{4}\right.$ complexes were prepared by following a general procedure. Specific details are given below for a particular complex.

(a) $\left[\mathbf{R u}(\mathbf{b p y})_{2}(\mathbf{b z t s c}-\mathbf{H})\right] \mathbf{C l O}_{4} \cdot \mathbf{H}_{2} \mathrm{O}$. To a solution of $\left[\mathrm{Ru}(\mathrm{bpy})_{2} \mathrm{Cl}_{2}\right] \cdot$ $2 \mathrm{H}_{2} \mathrm{O}(100 \mathrm{mg}, 0.19 \mathrm{mmol})$ in ethanol $(30 \mathrm{~mL})$ was added $\mathrm{AgNO}_{3}(65$ $\mathrm{mg}, 0.38 \mathrm{mmol})$. The mixture was warmed and stirred for $30 \mathrm{~min}$. The

(4) Giordino, P. J.; Bock, C. R.; Wrighton, J. M. S. Am. Chem. Soc. 1978 100,6960 .

(5) Kober, E. M.; Casper, J. V.; Sullivan, B. P.; Meyer, T. J. Inorg. Chem. 1988, 27, 4587. 
Table 1. Crystallographic Data for Hbztsc-OMe, $\left[\mathrm{Ru}(\mathrm{bpy})_{2}\left(\mathrm{bztsc}-\mathrm{NO}_{2}\right)\right] \mathrm{ClO}_{4} \cdot \mathrm{H}_{2} \mathrm{O} \cdot 75 \mathrm{C}_{6} \mathrm{H}_{6}$ and $\left[\mathrm{Ru}(\mathrm{bpy})_{2}(\operatorname{actsc})\right] \mathrm{ClO} \mathrm{O}_{4}$

\begin{tabular}{|c|c|c|c|}
\hline & Hbztsc-OMe & $\begin{array}{c}{\left[\mathrm{Ru}(\mathrm{bpy})_{2}\left(\mathrm{bztsc}-\mathrm{NO}_{2}\right)\right]} \\
\mathrm{ClO}_{4} \cdot \mathrm{H}_{2} \mathrm{O} \cdot 0.75 \mathrm{C}_{6} \mathrm{H}_{6}\end{array}$ & {$\left[\mathrm{Ru}(\mathrm{bpy})_{2}(\mathrm{actsc})\right] \mathrm{ClO}_{4}$} \\
\hline empirical formula & $\mathrm{C}_{9} \mathrm{H}_{11} \mathrm{~N}_{3} \mathrm{OS}$ & $\mathrm{C}_{32.50} \mathrm{H}_{29.50} \mathrm{~N}_{8} \mathrm{O}_{7} \mathrm{SClRu}$ & $\mathrm{C}_{24} \mathrm{H}_{24} \mathrm{~N}_{7} \mathrm{O}_{4} \mathrm{SClRu}$ \\
\hline & 209.27 & 812.73 & 643.07 \\
\hline space group & monoclinic $P 2{ }_{1} / c$ & triclinic $P \overline{1}$ & monoclinic $P 2_{1} / c$ \\
\hline$a, \AA$ & $7.868(2)$ & $13.2883(15)$ & $13.978(3)$ \\
\hline$b, \AA$ & $13.524(3)$ & $13.4632(20)$ & $15.823(3)$ \\
\hline$c, \AA$ & $10.051(2)$ & $21.6614(12)$ & $12.541(4)$ \\
\hline$\alpha, \operatorname{deg}$ & 90 & $83.475(8)$ & 90 \\
\hline$\beta, \operatorname{deg}$ & $106.31(3)$ & $80.067(7)$ & $104.99(3)$ \\
\hline$\gamma, \operatorname{deg}$ & 90 & $63.611(10)$ & 90 \\
\hline$V, \AA^{3}$ & $1026.5(4)$ & $3416.4(7)$ & $2679.2(11)$ \\
\hline$Z$ & 4 & 4 & 4 \\
\hline$\lambda, \AA$ & 0.71073 & 0.71073 & 0.71073 \\
\hline crystal size, mm & $0.30 \times 0.25 \times 0.2$ & $0.40 \times 0.25 \times 0.25$ & $0.60 \times 0.40 \times 0.05$ \\
\hline$T, \mathrm{~K}$ & 293 & 298 & 295 \\
\hline$\mu, \mathrm{cm}^{-1}$ & 2.86 & 6.426 & 7.911 \\
\hline \multirow[t]{2}{*}{$R$ indices } & $\mathrm{R} 1=0.0342^{a}$ & $R_{\mathrm{f}}=0.051^{c}$ & $R_{\mathrm{f}}=0.033^{c}$ \\
\hline & $\mathrm{wR} 2=0.0888^{b}$ & $R_{\mathrm{W}}=0.063^{d}$ & $R_{\mathrm{W}}=0.039^{d}$ \\
\hline GOF & $1.116^{e}$ & $2.72^{f}$ & $1.69^{f}$ \\
\hline
\end{tabular}

${ }^{a} \mathrm{R} 1=\sum|| F_{\mathrm{o}}|-| F_{\mathrm{c}}|| / \sum\left|F_{\mathrm{o}}\right| \cdot{ }^{b} \mathrm{wR} 2=\left[\sum\left\{w\left(F_{\mathrm{o}}{ }^{2}-F_{\mathrm{c}}{ }^{2}\right)^{2}\right\} / \sum\left\{w\left(F_{\mathrm{o}}{ }^{2}\right)\right\}\right]^{1 / 2} \cdot{ }^{c} R_{\mathrm{f}}=\sum|| F_{\mathrm{o}}|-| F_{\mathrm{c}}|| / \sum\left|F_{\mathrm{o}}\right| \cdot{ }^{d} R_{\mathrm{w}}=\left[\sum w\left(\left|F_{\mathrm{o}}\right|-\left|F_{\mathrm{c}}\right|\right)^{2} / \sum w\left(F_{\mathrm{o}}\right)^{2}\right]^{1 / 2} \cdot{ }^{e} \mathrm{GOF}$ $=\left[\sum\left(w\left(F_{\mathrm{o}}^{2}-F_{\mathrm{c}}{ }^{2}\right)^{2}\right) /(M-N)\right]^{1 / 2}$, where $M$ is the number of reflections and $N$ is the number of parameters refined. ${ }^{f} \mathrm{GOF}=\left[\sum\left(w\left(\left|F_{\mathrm{o}}\right|-\left|F_{\mathrm{c}}\right|\right)^{2}\right) /(M\right.$ $-N)]^{1 / 2}$, where $M$ is the number of reflections and $N$ is the number of parameters refined.

deposited $\mathrm{AgCl}$ was separated by filtration, and to the filtrate were added $\mathrm{Hbztsc}-\mathrm{H}(36 \mathrm{mg}, 0.20 \mathrm{mmol})$ and triethylamine $(0.04 \mathrm{~mL}, 0.29$ mmol). The solution was heated at reflux for $2 \mathrm{~h}$. It was then concentrated to $\sim 10 \mathrm{~mL}$, and a saturated aqueous solution of $\mathrm{NaClO}_{4}$ $(0.5 \mathrm{~mL})$ was added to afford a precipitate of $\left[\mathrm{Ru}(\mathrm{bpy})_{2}(\mathrm{bztsc}-\mathrm{H})\right]$ $\mathrm{ClO}_{4}$, which was collected by filtration, washed with cold water, and dried in vacuo over $\mathrm{P}_{4} \mathrm{O}_{10}$. Recrystallization from $1: 3$ acetonitrilebenzene solution gave $\left[\mathrm{Ru}(\mathrm{bpy})_{2}(\mathrm{bztsc}-\mathrm{H})\right] \mathrm{ClO}_{4} \cdot \mathrm{H}_{2} \mathrm{O}$ as a dark crystalline solid. Yield, $75 \%$.

All the $\left[\mathrm{Os}(\mathrm{bpy})_{2}(\mathrm{tsc})\right] \mathrm{ClO}_{4} \cdot \mathrm{H}_{2} \mathrm{O}$ complexes were prepared by following a general procedure. Specific details are given below for a particular complex.

(b) $\left[\mathrm{Os}(\mathbf{b p y})_{2}(\mathbf{b z t s c}-\mathbf{H})\right] \mathrm{ClO}_{4} \cdot \mathbf{H}_{2} \mathbf{O} \cdot\left[\mathrm{Os}(\mathrm{bpy})_{2} \mathrm{Br}_{2}\right](100 \mathrm{mg}, 0.15$ $\mathrm{mmol}), \mathrm{Hbztsc}-\mathrm{H}(28 \mathrm{mg}, 0.16 \mathrm{mmol})$ and triethylamine $(0.02 \mathrm{~mL}$, $0.14 \mathrm{mmol})$ were refluxed in 1:1 ethanol-water $(40 \mathrm{~mL})$ for $6 \mathrm{~h}$. The solution was then concentrated to $\sim 10 \mathrm{~mL}$, and a saturated solution of $\mathrm{NaClO}_{4}(0.5 \mathrm{~mL})$ was added. $\left[\mathrm{Os}(\mathrm{bpy})_{2}(\mathrm{bztsc}-\mathrm{H})\right] \mathrm{ClO}_{4}$ precipitated as a reddish-brown solid, which was collected by filtration, washed with cold water, and dried in vacuo over $\mathrm{P}_{4} \mathrm{O}_{10}$. Recrystallization from $1: 3$ acetronitrile-benzene solution gave $\left[\mathrm{Os}(\mathrm{bpy})_{2}(\mathrm{bztsc}-\mathrm{H})\right] \mathrm{ClO}_{4} \cdot \mathrm{H}_{2} \mathrm{O}$ as a dark crystalline solid. Yield, $70 \%$.

Physical Measurements. Microanalyses $(\mathrm{C}, \mathrm{H}, \mathrm{N})$ were performed using a Perkin-Elmer 240C elemental analyzer. IR spectra were obtained on a Perkin-Elmer 783 spectrometer with samples prepared as $\mathrm{KBr}$ pellets. Electronic spectra were recorded on Simadzu UV 240 spectrophotometer. Magnetic susceptibilities were measured using a PAR 155 vibrating sample magnetometer fitted with a Walker Scientific L75FBAL magnet. ${ }^{1} \mathrm{H}$ NMR spectra were recorded on a Brucker AC200 NMR spectrometer using TMS as the internal standard. Solution electrical conductivities were measured using a Philips PR 9500 bridge with a solute concentration of $10^{-3} \mathrm{M}$. Electrochemical measurements were made using a PAR model 273 potentiostat. A platinum disk or graphite working electrode, a platinum wire auxiliary electrode, and an aqueous saturated calomel reference electrode (SCE) were used in a three-electrode configuration. Dinitrogen gas was purified by successively bubbling it through alkaline dithionite and concentrated sulfuric acid. All electrochemical experiments were performed under a dinitrogen atmosphere. All electrochemical data were collected at $298 \mathrm{~K}$ and are uncorrected for junction potentials. An RE $0089 X Y$ recorder was used to trace the voltammograms.

Crystallography of Hbztsc-OMe. Single crystals of Hbztsc-OMe were grown by slow diffusion of hexane into a dichloromethane solution of the complex. Selected crystal data and data collection parameters are given in Table 1 . The unit cell dimensions were determined by a least-squares fit of 30 machine-centered reflections $\left(15<2 \theta<30^{\circ}\right)$. Data were collected on a Siemens P3 diffractometer using graphite- monochromated Mo K $\alpha$ radiation $(\lambda=0.71073 \AA)$ for $\omega$ scans within the angular range $3.0-47.0^{\circ}$. Three standard reflections, used to check the crystal stability toward X-ray exposure, showed no significant intensity variation over the entire course of data collection. X-ray data reduction and structure solution and refinement were done using the SHELXTL, version 5.03, package. The structure was solved by the direct method. Final cycles of refinement converged with discrepancy indices of $\mathrm{R} 1=0.0342$ and $\mathrm{wR} 2=0.0888$.

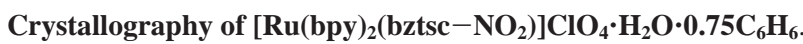
Single crystals of $\left[\mathrm{Ru}(\mathrm{bpy})_{2}\left(\mathrm{bztsc}-\mathrm{NO}_{2}\right)\right] \mathrm{ClO}_{4} \cdot \mathrm{H}_{2} \mathrm{O} \cdot 0.75 \mathrm{C}_{6} \mathrm{H}_{6}$ were grown by slow diffusion of benzene into an acetonitrile solution of the complex. Selected crystal data and data collection parameters are given in Table 1 . The unit cell dimensions were determined by a least-squares fit of 25 machine-centered reflections $(19.60<2 \theta<23.78)$. Data were collected on an Enraf-Nonius CAD-4 diffractometer using graphitemonochromated Mo K $\alpha$ radiation $(\lambda=0.71073 \AA)$ for $\theta-2 \theta$ scans with a maximum $2 \theta$ of $45^{\circ}$. Three standard reflections, used to check the crystal stability toward X-ray exposure, showed no significant intensity variation over the entire course of data collection. X-ray data reduction, structure solution, and structure refinement were done using the NRCVAX package. The structure was solved by the Patterson method. The solvents of crystallization have been observed to be disordered. Final cycles of refinement converged with discrepancy indices of $R_{\mathrm{f}}=0.051$ and $R_{\mathrm{w}}=0.063$.

Crystallography of $\left[\mathrm{Ru}(\mathrm{bpy})_{2}(\mathbf{a c t s c})\right] \mathrm{ClO}_{4}$. Single crystals of $[\mathrm{Ru}-$ (bpy) $)_{2}($ actsc $) \mathrm{ClO}_{4}$ were grown by slow diffusion of ethanol into a dichloromethane solution of the complex. Selected crystal data and data collection parameters are given in Table 1 . The unit cell dimensions were determined by a least-squares fit of 25 machine-centered reflections $\left(15.56<2 \theta<27.12^{\circ}\right)$. Data were collected on an Enraf-Nonius CAD-4 diffractometer using grafite-monochromated Mo K $\alpha$ radiation $\left(\lambda=0.71073 \AA\right.$ ) for $\theta-2 \theta$ scans with a maximum $2 \theta$ of $50^{\circ}$. Three standard reflections, used to check the crystal stability toward X-ray exposure, showed no significant intensity variation over the entire course of data collection. X-ray data reduction and structure solution and refinement were done using the NRCVAX package. The structure was solved by the Patterson method. Final cycles of refinement converged with discrepancy indices of $R_{\mathrm{f}}=0.033$ and $R_{\mathrm{w}}=0.039$.

\section{Results and Discussion}

Thiosemicarbazones of five para-substituted benzaldehydes (Hbztsc-R, 2) have been used in the present work. Reaction of these ligands with $\left[\mathrm{Ru}(\mathrm{bpy})_{2}(\mathrm{EtOH})_{2}\right]^{2+}$, generated in situ from $\left[\mathrm{Ru}(\mathrm{bpy})_{2} \mathrm{Cl}_{2}\right]$ by displacing the two chloride ligands by $\mathrm{Ag}^{+}$in ethanol, proceeds smoothly in the presence of a base to 
Table 2. Microanalytical and Electronic Spectral Data of the $\left[\mathrm{M}(\mathrm{bpy})_{2}(\mathrm{tsc})\right] \mathrm{ClO}_{4}$ Complexes

\begin{tabular}{|c|c|c|c|c|}
\hline compound & \multicolumn{3}{|c|}{ microanalytical data ${ }^{a}(\%)$} & electronic spectral data ${ }^{b}$ \\
\hline$\left[\mathrm{Ru}(\mathrm{bpy})_{2}(\mathrm{bztsc}-\mathrm{OMe})\right] \mathrm{ClO}_{4}$ & $\begin{array}{c}48.2 \\
(48.3)\end{array}$ & $\begin{array}{c}3.8 \\
(3.6)\end{array}$ & $\begin{array}{c}13.7 \\
(13.6)\end{array}$ & $525(8800), 424^{c}(5800), 380(17500)$ \\
\hline$\left[\mathrm{Ru}(\mathrm{bpy})_{2}(\mathrm{bztsc}-\mathrm{Me})\right] \mathrm{ClO}_{4}$ & $\begin{array}{c}49.5 \\
(49.4)\end{array}$ & $\begin{array}{c}3.7 \\
(3.7)\end{array}$ & $\begin{array}{c}13.9 \\
(13.9)\end{array}$ & $516(9300), 452^{c}(7100), 372(17400)$ \\
\hline$\left[\mathrm{Ru}(\mathrm{bpy})_{2}(\mathrm{bztsc}-\mathrm{H})\right] \mathrm{ClO}_{4}$ & $\begin{array}{c}49.0 \\
(48.7)\end{array}$ & $\begin{array}{c}3.6 \\
(3.5)\end{array}$ & $\begin{array}{c}14.5 \\
(14.2)\end{array}$ & $520(9000), 460^{c}(7000), 385(14800)$ \\
\hline$\left[\mathrm{Ru}(\mathrm{bpy})_{2}(\mathrm{bztsc}-\mathrm{Cl})\right] \mathrm{ClO}_{4}$ & $\begin{array}{c}46.5 \\
(46.3)\end{array}$ & $\begin{array}{c}3.4 \\
(3.2)\end{array}$ & $\begin{array}{c}13.6 \\
(13.5)\end{array}$ & $512(8700), 412^{c}(12900), 376(14700)$ \\
\hline$\left[\mathrm{Ru}(\mathrm{bpy})_{2}\left(\mathrm{bztsc}-\mathrm{NO}_{2}\right)\right] \mathrm{ClO}_{4}$ & $\begin{array}{c}45.8 \\
(45.7)\end{array}$ & $\begin{array}{c}3.0 \\
(3.1)\end{array}$ & $\begin{array}{c}14.9 \\
(15.2)\end{array}$ & $510(20000), 453^{c}(12000), 350(25000)$ \\
\hline$\left[\mathrm{Ru}(\mathrm{bpy})_{2}(\mathrm{actsc})\right] \mathrm{ClO}_{4}$ & $\begin{array}{c}45.1 \\
(44.8)\end{array}$ & $\begin{array}{c}3.8 \\
(3.7)\end{array}$ & $\begin{array}{c}15.3 \\
(15.2)\end{array}$ & $624^{c}(15000), 492(8500), 444^{c}(7000), 360^{c}(8700), 328(10000)$ \\
\hline$\left[\mathrm{Os}(\mathrm{bpy})_{2}(\mathrm{bztsc}-\mathrm{OMe})\right] \mathrm{ClO}_{4}$ & $\begin{array}{c}42.9 \\
(43.0)\end{array}$ & $\begin{array}{c}3.3 \\
(3.2)\end{array}$ & $\begin{array}{c}12.3 \\
(12.1)\end{array}$ & $539^{c}(6000), 511^{c}(6500), 433(8800), 388(10800)$ \\
\hline$\left[\mathrm{Os}(\mathrm{bpy})_{2}(\mathrm{bztsc}-\mathrm{Me})\right] \mathrm{ClO}_{4}$ & $\begin{array}{c}44.1 \\
(43.9)\end{array}$ & $\begin{array}{c}3.3 \\
(3.3)\end{array}$ & $\begin{array}{c}12.4 \\
(12.3)\end{array}$ & $532^{c}(6200), 504^{c}(8000), 424^{c}(102000), 384(11900)$ \\
\hline$\left[\mathrm{Os}(\mathrm{bpy})_{2}(\mathrm{bztsc}-\mathrm{H})\right] \mathrm{ClO}_{4}$ & $\begin{array}{c}43.3 \\
(43.1)\end{array}$ & $\begin{array}{c}3.2 \\
(3.1)\end{array}$ & $\begin{array}{c}12.7 \\
(12.6)\end{array}$ & $541(11700), 467^{c}(15400), 433^{c}(16800), 397(19000)$ \\
\hline$\left[\mathrm{Os}(\mathrm{bpy})_{2}(\mathrm{bztsc}-\mathrm{Cl})\right] \mathrm{ClO}_{4}$ & $\begin{array}{c}41.4 \\
(41.3)\end{array}$ & $\begin{array}{c}3.0 \\
(2.8)\end{array}$ & $\begin{array}{c}12.2 \\
(12.0)\end{array}$ & $528^{c}(8600), 504^{c}(10100), 412(13600), 336^{c}(14600)$ \\
\hline$\left[\mathrm{Os}(\mathrm{bpy})_{2}\left(\mathrm{bztsc}-\mathrm{NO}_{2}\right)\right] \mathrm{ClO}_{4}$ & $\begin{array}{c}40.6 \\
(40.7)\end{array}$ & $\begin{array}{c}2.9 \\
(2.8)\end{array}$ & $\begin{array}{c}13.8 \\
(13.6)\end{array}$ & $533^{c}(9600), 492^{c}(10700), 353(19700)$ \\
\hline$\left[\mathrm{Os}(\mathrm{bpy})_{2}(\mathrm{actsc})\right] \mathrm{ClO}_{4}$ & $\begin{array}{c}39.6 \\
(39.4)\end{array}$ & $\begin{array}{c}3.4 \\
(3.3)\end{array}$ & $\begin{array}{c}13.6 \\
(13.4)\end{array}$ & $700(2100), 490^{c}(6500), 408^{c}(7200), 350(7800)$ \\
\hline
\end{tabular}

afford the $\left[\mathrm{Ru}(\mathrm{bpy})_{2}(\mathrm{bztsc}-\mathrm{R})\right]^{+}$complexes, which have been isolated as perchlorate salts in the solid state. The analogous osmium complexes were synthesized by the reaction of [Os(bpy $)_{2} \mathrm{Br}_{2}$ ] with the respective thiosemicarbazone ligands in refluxing aqueous ethanol in the presence of triethylamine. Elemental (C, H, N) analytical data (Table 2) are in good agreement with the compositions of the complexes. All the complexes are diamagnetic, which corresponds to the +2 state of the metals (low-spin $\mathrm{d}^{6}, S=0$ ) in these complexes. Because bpy is a symmetric bidentate ligand, the $\left[\mathrm{M}(\mathrm{bpy})_{2}(\mathrm{bztsc}-\mathrm{R})\right]^{+}$ complexes may exist in only one stereoisomeric form. However, because of the different possible coordination modes of the thiosemicarbazone ligands, ${ }^{2,3,6}$ linkage isomers are possible for these complexes. To find out the mode of coordination of the benzaldehyde thiosemicarbazone ligands in these complexes, the molecular structure of a representative complex, viz., [Ru(bpy) $)_{2}\left(\right.$ bztsc $\left.\left.-\mathrm{NO}_{2}\right)\right] \mathrm{ClO}_{4}$, was determined by X-ray crystallography. A view of the complex cation is shown in Figure 1, and selected bond distances and angles are listed in Table 3. The $\mathrm{N}_{5} \mathrm{~S}$ coordination sphere around ruthenium is a distorted octahedral, which is reflected in all the bond angles with ruthenium as the central atom. The bond distances in the Ru(bpy) $)_{2}$ fragment are all quite normal, as observed in structurally characterized complexes containing the $\mathrm{Ru}(\mathrm{bpy})_{2}$ moiety. ${ }^{7}$ The thiosemicarbazone ligand is coordinated to ruthenium as a bidentate $\mathrm{N}, \mathrm{S}$ donor ligand forming a four-membered chelate ring with a bite angle of $\sim 67^{\circ}$. The bond distances in the Ru(bztsc $-\mathrm{NO}_{2}$ ) fragment compare well with those observed in the same fragment of the $\left[\mathrm{Ru}\left(\mathrm{PPh}_{3}\right)_{2}\left(\mathrm{bztsc}-\mathrm{NO}_{2}\right)_{2}\right]$ complex. ${ }^{3}$ The spectral and electrochemical properties of all the $\left[\mathrm{M}(\mathrm{bpy})_{2^{-}}\right.$

(6) (a) West, D. X.; Padhye, S. B.; Sonawane, P. B. Struct. Bonding 1991, 76, 1. (b) Tian, Y. P.; Duan, C. Y.; Lu, Z. L.; You, X. Z.; Fun, H. K.; Sivakumar, K. Polyhedron 1996, 15, 2263. (c) Zheng, H. G.; Zeng, D. X.; Xin, X. Q.; Wong, W. T. Polyhedron 1997, 16, 3499.

(7) (a) Eggleston, D. S.; Goldsby, K. A.; Hodgson, D. J.; Meyer, T. J. Inorg. Chem. 1985, 24, 4573. (b) Vliet, P. M. v.; Haasnoot, J. G.; Reedijk, J. Inorg. Chem. 1994, 33, 1934. (c) Yamaguchi, M.; Machiguchi, K.; Mori, T.; Kikuchi, K.; Ikemoto, I.; Yamagishi, T. Inorg. Chem. 1996, 35, 143. (d) Yamamari, K.; Nozaki, T.; Fuyuhiro, A.; Kushi, Y.; Kaijaki, S. J. Chem. Soc, Dalton Trans. 1996, 2851. $(\text { bztsc-R) }]^{+}$complexes are similar (vide infra), and hence, they all are assumed to have the same structure as $\left[\mathrm{Ru}(\mathrm{bpy})_{2}(\mathrm{bztsc}-\right.$ $\left.\left.\mathrm{NO}_{2}\right)\right]^{+}$.

Formation of four-membered chelate ring by the bztsc-R ligands, as was observed in $\left[\mathrm{Ru}\left(\mathrm{PPh}_{3}\right)_{2}(\text { saltsc })_{2}\right],{ }^{2}$ even after removal of the hydroxy group from the salicylaldehyde thiosemicarbazone ligand and replacement of triphenylphosphine by the less bulky bipyridine as coligand, clearly indicates that neither intramolecular hydrogen bonding nor steric interaction of the thiosemicarbazone ligands with $\mathrm{PPh}_{3}$ is the actual driving force behind the observed unusual coordination mode. However, these modification exercises led us to the conclusion that the restrictions in five-membered ring formation must be arising primarily from the thiosemicarbazone ligand itself. To find out the origin of such a four-membered ring formation, the stereochemistry of benzaldehyde thiosemicarbazone was first taken into account. Owing to the restricted rotation about the $\mathrm{C}=\mathrm{N}$ bond, the Hbztsc $-\mathrm{R}$ ligands may exist in two different geometric isomeric forms ( $\mathbf{4}$ and $\mathbf{5}$ ). The structure determination
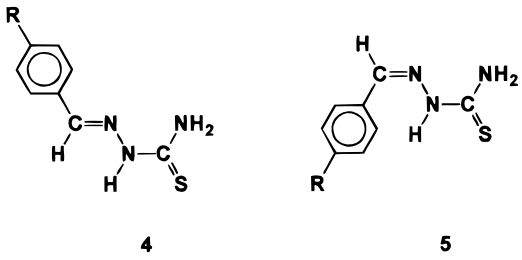

of one representative ligand, viz., Hbztsc-OMe, by X-ray crystallography shows (Figure 2, Table 3) that the free ligand exists in the thione form (supported by the presence of hydrazinic $\mathrm{N}-\mathrm{H}$ and a $\mathrm{C}-\mathrm{S}$ distance of $1.695 \AA$, which is much shorter than a $\mathrm{C}-\mathrm{S}$ single bond ${ }^{8}$ ) and corresponds to structure 4 where the aryl group is trans to the hydrazinic nitrogen. Starting from the free ligand five-membered chelate, ring formation can only take place via rotation about the $\mathrm{C}-\mathrm{N}$ (hydrazinic) single bond followed by tautomerization to the thiol form and dissociation of the thiolate proton upon complexation.

(8) Collins, R. C.; Davis, R. E. Acta Crystallogr., Sect. B 1978, 34, 283. 


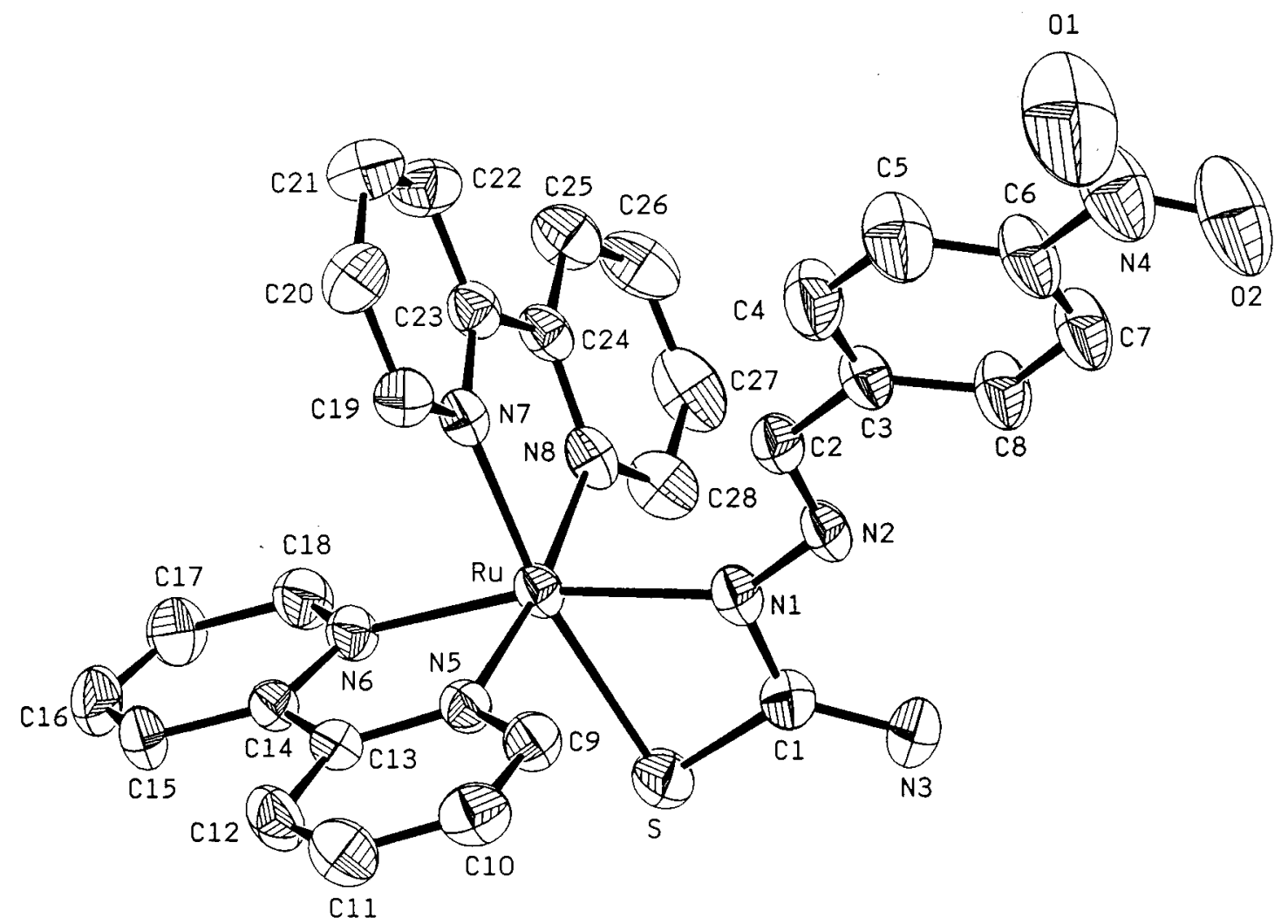

Figure 1. Structure of $\left[\mathrm{Ru}(\mathrm{bpy})_{2}\left(\mathrm{bztsc}-\mathrm{NO}_{2}\right)\right]^{+}$complex.

To have an idea about the possible restrictions in forming such a five-membered ring, a computer model of $\left[\mathrm{Ru}(\mathrm{bpy})_{2}\right.$ (bztsc$\mathrm{H})]^{+}$was constructed, ${ }^{9}$ forcing five-membered chelate ring formation by the thiosemicarbazone ligand and assuming the ligand to be planar and retaining its geometry in this coordination mode. Our modeling studies show that in this coordination mode, the phenyl ring of the thiosemicarbazone ligand comes in contact with the metal and also and more severely with the pyridine ring (of one bpy) trans to the thiolate sulfur (Figure 3 ). Hence, such a coordination mode appears to be impossible by the bezaldehyde thiosemicarbazones. This exercise also clearly indicates that the unusual four-membered chelate ring was formed because of the combined effect of (i) restricted rotation about the $\mathrm{C}=\mathrm{N}$ bond and (ii) steric bulk of the phenyl ring of bztsc $-\mathrm{R}$ ligands. Restriction in rotation about the $\mathrm{C}=\mathrm{N}$ bond is an intrinsic property of such a double bond, which cannot be overcome. However, the steric bulk of the aryl group can easily be changed by changing this group altogether. Our modeling studies indicate that stable five-membered chelate ring formation by thiosemicarbazone ligands is possible only when the steric bulk of the group trans to the hydrazinic nitrogen is reduced to such an extent that it does not come in contact with the metal as well as with any other coordinated ligand. With this strategy in mind, we did similar molecular modeling studies on a similar complex using acetone thiosemicarbazone instead of benzaldehyde thiosemicarbazone. This modification turned out to be sterically favorable for the expected five-membered ring formation (Figure 3). Encouraged by this result, two acetone thiosemicarbazone complexes, viz., $\left[\mathrm{M}(\mathrm{bpy})_{2}(\mathrm{actsc})\right]^{+}(\mathrm{M}=\mathrm{Ru}$, Os), have been synthesized following the same procedures as before. Structure determination on the $\left[\mathrm{Ru}(\mathrm{bpy})_{2}(\mathrm{actsc})\right]^{+}$ complex indeed proved our speculation to be correct. The

(9) (a) Mealli, C.; Proserpio, D. M. CACAO, version 4.0; Firenze, Italy, 1994. (b) Mealli, C.; Proserpio, D. M. J. Chem Educ. 1990, 67, 399. structure is shown in Figure 4, and relevant bond distances and angles are given in Table 3 . The actsc ligand is coordinated to ruthenium, forming a five-membered chelate ring with a bite angle of $\sim 81^{\circ}$. There are significant differences in bond distances and angles in the $\mathrm{Ru}\left(\right.$ actsc) and $\mathrm{Ru}\left(\mathrm{bztsc}-\mathrm{NO}_{2}\right.$ ) fragments of the $\left[\mathrm{Ru}(\mathrm{bpy})_{2}(\mathrm{actsc})\right]^{+}$and $\left[\mathrm{Ru}(\mathrm{bpy})_{2}(\mathrm{bztsc}-\right.$ $\left.\left.\mathrm{NO}_{2}\right)\right]^{+}$complexes, respectively, which might be attributed to the difference in coordination modes and ring sizes.

${ }^{1} \mathrm{H}$ NMR spectra of the $\left[\mathrm{M}(\mathrm{bpy})_{2}(\mathrm{tsc})\right]^{+}$complexes were recorded in $\mathrm{CDCl}_{3}$ solution. The aromatic region $(6.5-9.6 \mathrm{ppm})$ is rather complex because of the overlap of the signals. However, the intensity measurement of these signals corresponds to the total number of aromatic protons present in the respective complexes. In all the $\left[\mathrm{M}(\mathrm{bpy})_{2}(\mathrm{bztsc}-\mathrm{R})\right]^{+}$complexes the azomethine proton shows a distinct resonance near $9.9 \mathrm{ppm}$ and the two amine hydrogens are observed near $5.8 \mathrm{ppm}$. Distinct methyl signals are observed in $\left[\mathrm{M}(\mathrm{bpy})_{2}(\mathrm{bztsc}-\mathrm{Me})\right] \mathrm{ClO}_{4}$ and $\left[\mathrm{M}(\mathrm{bpy})_{2}(\mathrm{bztsc}-\mathrm{OMe})\right] \mathrm{ClO}_{4}(\mathrm{M}=\mathrm{Ru}$, Os $)$ near 2.3 and 3.6 ppm, respectively, which are due to methyl and methoxy groups in the aryl fragment of the bztsc-Me and bztsc-OMe ligands. In the $\left[\mathrm{M}(\mathrm{bpy})_{2}(\mathrm{actsc})\right]^{+}$complexes, the two methyl signals of actsc ligand are observed near 2.07 and $2.08 \mathrm{ppm}$. Infrared spectra of the $\left[\mathrm{M}(\mathrm{bpy})_{2}(\mathrm{tsc}) \mathrm{ClO}_{4}\right.$ complexes showed many vibrations of different intensities below $1600 \mathrm{~cm}^{-1}$. Assignment of all bands to specific vibrations has not been attempted. However, some useful information is obtained by careful examination of these spectra and also by their comparison with the spectra of cis-[M(bpy $\left.)_{2} \mathrm{X}_{2}\right](\mathrm{X}=\mathrm{Cl}, \mathrm{Br})$. For example, the $\mathrm{Ru}-\mathrm{Cl}$ stretches observed near $330 \mathrm{~cm}^{-1}$ in cis-[Ru(bpy) $\left.{ }_{2} \mathrm{Cl}_{2}\right]$ are absent in all $\left[\mathrm{Ru}(\mathrm{bpy})_{2}(\mathrm{tsc}) \mathrm{ClO}_{4}\right.$ complexes, as expected. There are some common vibrations in the spectrum of cis-[Ru(bpy) $\left.)_{2} \mathrm{Cl}_{2}\right]$ and $\left[\mathrm{Ru}(\mathrm{bpy})_{2}\right.$ (tsc) $\mathrm{ClO}_{4}$ (e.g., vibrations near 810, 770,660 , and $425 \mathrm{~cm}^{-1}$ ) that are probably due to the common $\mathrm{Ru}(\mathrm{bpy})_{2}$ moiety. Some additional vibrations are observed in 
Table 3. Selected Bond Distances and Bond Angles for $\mathrm{Hbztsc}-\mathrm{OMe},\left[\mathrm{Ru}(\mathrm{bpy})_{2}\left(\mathrm{bztsc}-\mathrm{NO}_{2}\right)\right] \mathrm{ClO}_{4}$, and $\left[\mathrm{Ru}(\mathrm{bpy})_{2}(\mathrm{actsc})\right] \mathrm{ClO}_{4}$

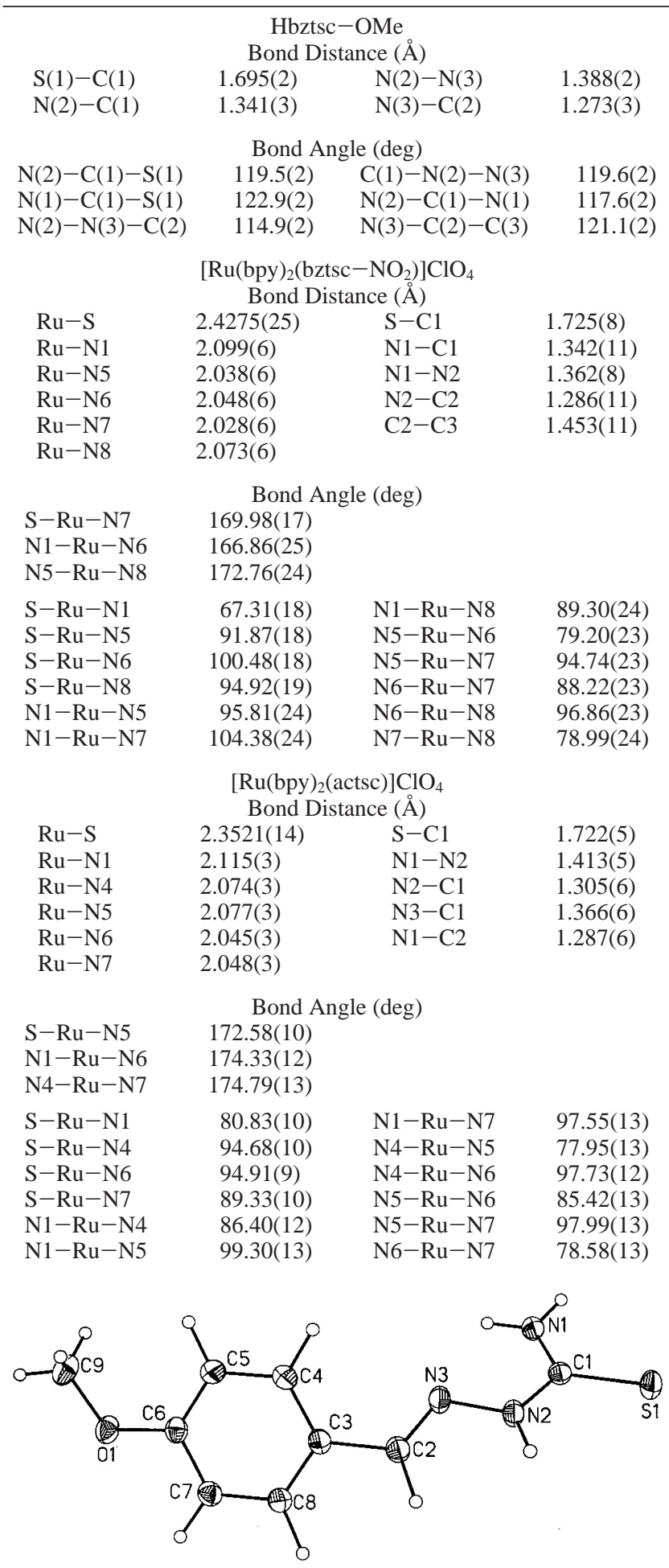

Figure 2. Structure of Hbztsc-OMe.

the spectra of the $\left[\mathrm{Ru}(\mathrm{bpy})_{2}(\mathrm{tsc})\right] \mathrm{ClO}_{4}$ complexes, of which an intense broad vibration near $1100 \mathrm{~cm}^{-1}$ and another intense sharp band near $625 \mathrm{~cm}^{-1}$ are due to the presence of perchlorate ion. The other new vibrations are obviously due to the coordinated tsc ligands. The infrared spectra of the osmium complexes are almost identical to their respective ruthenium analogues.

The $\left[\mathrm{M}(\mathrm{bpy})_{2}(\mathrm{tsc})\right] \mathrm{ClO}_{4}$ complexes are soluble in common organic solvents such as ethanol, acetone, dichloromethane, acetonitrile, etc., producing solutions of different shades of brown. Conductance measurement in acetonitrile solution shows that these complexes behave as 1:1 electrolytes $\left(\Lambda_{M}=150-\right.$ $\left.160 \Omega^{-1} \mathrm{~cm}^{2} \mathrm{M}^{-1}\right)$. Electronic spectra of these complexes were recorded in acetonitrile solution. Spectral data are displayed in Table 2, and selected spectra are shown in Figure 5. Each complex shows several intense absorptions in the visible region that are probably due to allowed metal-to-ligand charge-transfer transitions. Multiple charge-transfer transitions in such mixedligand complexes may result from lower-symmetry splitting of the metal level, the presence of different acceptor orbitals, and the mixing of singlet and triplet configurations in the excited state through spin-orbit coupling. ${ }^{10}$ To have an insight into the nature of the observed charge-transfer transitions, qualitative EHMO calculations have been performed ${ }^{9}$ on a model of the $\left[\mathrm{M}(\mathrm{bpy})_{2}(\mathrm{bztsc}-\mathrm{R})\right]^{+}$complexes, which was computer-generated from $\left[\mathrm{M}(\mathrm{bpy})_{2}(\mathrm{bztsc}-\mathrm{H})\right]^{+}$by replacing the phenyl group of bztsc $-\mathrm{H}$ by hydrogen. The coordination mode of thiosemicarbazone ligand, as observed in $\left[\mathrm{Ru}(\mathrm{bpy})_{2}\left(\mathrm{bztsc}-\mathrm{NO}_{2}\right)\right]^{+}$, has been retained. The partial MO diagram is shown in Figure 6, and a composition of selected molecular orbitals is shown in Table 4. The highest occupied molecular orbital (HOMO) and the next two occupied orbitals (HOMO-1and HOMO-2) have major contributions from the metal $t_{2}$ orbitals and much less contribution from 2,2'-bipyridine and thiosemicarbazone ligand. Hence, these three filled orbitals may be attributed to the metal $\mathrm{t}_{2}$ orbitals. There are three low-lying unoccupied molecular orbitals. The lowest unoccupied molecular orbital (LUMO) and the next unoccupied orbital (LUMO+1) are almost completely $\pi^{*}$ orbitals of bpy, while the third unoccupied orbital (LU$\mathrm{MO}+2$ ) is localized almost entirely on the uncoordinated imine bond of the thiosemicarbazone ligand. Hence, LUMO + 2 may be assumed to be an imine $\pi^{*}$ orbital of the bztsc $-\mathrm{R}$ ligands. The charge-transfer transitions observed in the $\left[\mathrm{M}(\mathrm{bpy})_{2}\right.$ (bztsc$\mathrm{R})]^{+}$complexes may therefore be assigned to transitions occurring from the filled metal $t_{2}$ levels to the $\pi^{*}$ orbitals of bpy and $\pi^{*}$ (imine) orbital of the bztsc $-\mathrm{R}$ ligands.

Similar EHMO calculations on the two $\left[\mathrm{M}(\mathrm{bpy})_{2}(\mathrm{actsc})\right]^{+}$ complexes show that the three filled orbitals (HOMO, HOMO1 , and HOMO-2) are again basically metal $t_{2}$ orbitals, and among the three low-lying unoccupied molecular orbitals, the first two vacant orbitals (LUMO and LUMO +1 ) are $\pi^{*}$ orbitals of bpy as before (Table 4). However, unlike the [M(bpy) ${ }_{2}-$ $($ bztsc $-\mathrm{R})]^{+}$complexes, LUMO +2 in these complexes is a bpy $\pi^{*}$ orbital, and the imine $\pi^{*}$ orbital of actsc is of much higher energy. This difference in the relative stability of the $\pi^{*}$ (imine) orbital of the two thiosemicarbazone ligands probably results from the difference in their coordination modes. In the bztsc- $\mathrm{R}$ complexes, the imine fragment of bztsc $-\mathrm{R}$ ligands does not participate in coordination, while in the actsc complexes, the imine nitrogen is coordinated to the metal. The charge-transfer transitions observed in the $\left[\mathrm{M}(\mathrm{bpy})_{2}(\mathrm{actsc})\right]^{+}$complexes may therefore be assigned to transitions taking place from the metal $\mathrm{t}_{2}$ orbitals to the $\pi^{*}$ orbitals of $2,2^{\prime}$-bipyridine.

Electron-transfer properties of the $\left[\mathrm{M}(\mathrm{bpy})_{2}(\mathrm{bztsc}-\mathrm{R})\right] \mathrm{ClO}_{4}$ complexes were studied in acetonitrile solution (0.1 M TEAP) by cyclic voltammetry. Each complex shows two metal-centered oxidative responses on the positive side of SCE and two ligandcentered reductive responses on the negative side. Voltammetric

(10) (a) Pankuch, B. J.; Lacky, D. E.; Crosby, G. A. Phys. Chem. 1980, 84, 2061. (b) Decurtis, S.; Felix, F.; Ferguson, J.; Gudel, H. U.; Ludi, A. J. Am. Chem. Soc. 1980, 102, 4102. (c) Ceulemans, A.; Vanquickenborne, L. G. J. Am. Chem. Soc. 1981, 103, 2238. (d) Kober, E. M.; Meyer, T. J. Inorg. Chem. 1982, 21, 3967. 
(a)

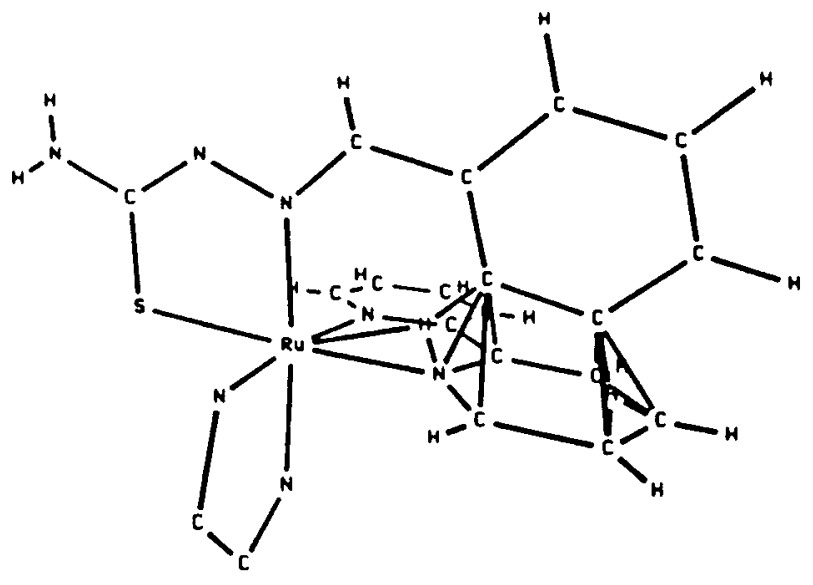

(b)

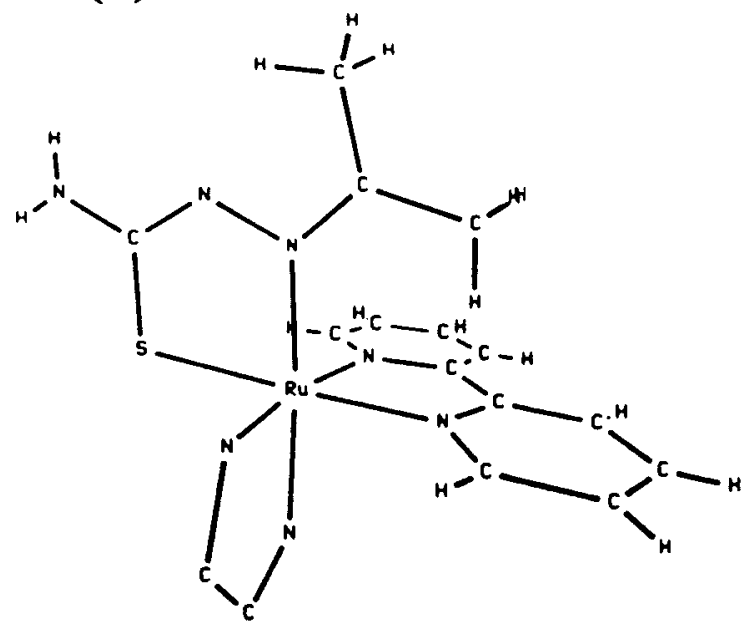

Figure 3. Steric interaction in (a) $\left[\mathrm{Ru}(\mathrm{bpy})_{2}(\mathrm{bztsc}-\mathrm{H})\right]^{+}$and (b) $\left[\mathrm{Ru}(\mathrm{bpy})_{2}(\mathrm{actsc})\right]^{+}$. The ring carbons of one bpy have been omited for clarity.

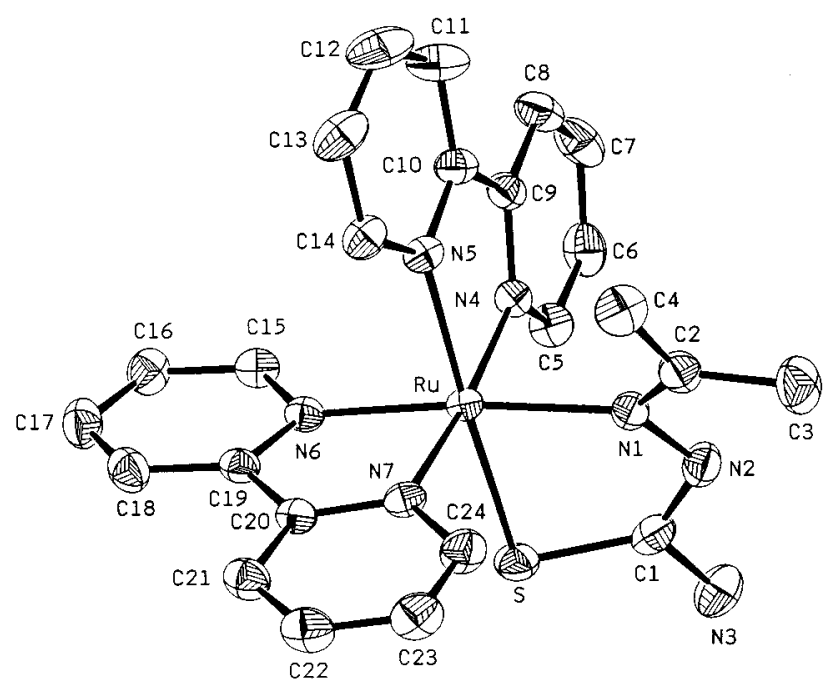

Figure 4. Structure of $\left[\mathrm{Ru}(\mathrm{bpy})_{2}(\mathrm{actsc})\right]^{+}$complex.

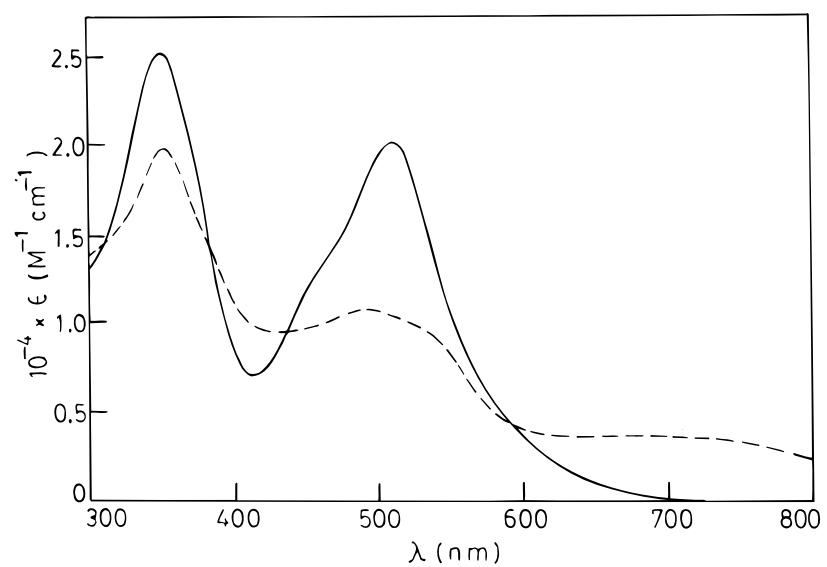

Figure 5. Electronic spectra of (a) $\left[\mathrm{Ru}(\mathrm{bpy})_{2}\left(\mathrm{bztsc}-\mathrm{NO}_{2}\right)\right]^{+}(-)$and (b) $\left[\mathrm{Os}(\mathrm{bpy})_{2}\left(\mathrm{bztsc}-\mathrm{NO}_{2}\right)\right]^{+}(---)$in acetonitrile solution.

data are presented in Table 5, and selected voltammograms are shown in Figure 7. The first oxidative response, observed in the range $0.18-0.58 \mathrm{~V}$ (all potentials are referenced to SCE), is assigned to the $\mathrm{M}^{\mathrm{II}}-\mathrm{M}^{\mathrm{III}}$ oxidation [eq 1]. This oxidation is

$$
\left[\mathrm{M}^{\mathrm{II}}(\mathrm{bpy})_{2}(\mathrm{bztsc}-\mathrm{R})\right]^{+} \rightleftharpoons\left[\mathrm{M}^{\mathrm{III}}(\mathrm{bpy})_{2}(\mathrm{bztsc}-\mathrm{R})\right]^{2+}+\mathrm{e}^{-}
$$

reversible with a peak-to-peak separation of $60-70 \mathrm{mV}$, and the anodic peak current $\left(i_{\mathrm{pa}}\right)$ is almost equal to the cathodic peak current $\left(i_{\mathrm{pc}}\right)$. The one-electron nature of this oxidation has been established by comparing its current height with that of a standard ferrocene/ferrocenium couple under identical experimental conditions. In $\left[\mathrm{Ru}(\mathrm{bpy})_{3}\right]^{2+}$, the ruthenium(II)-ruthenium(III) oxidation takes place at $1.30 \mathrm{~V},{ }^{11}$ and in the $\left[\mathrm{Ru}(\mathrm{bpy})_{2}(\mathrm{bztsc}-\mathrm{R})\right]^{+}$complexes the same oxidation is observed in the range $0.47-0.58 \mathrm{~V}$. Similarly, the osmium(II)-osmium(III) oxidation potential shifts from $0.84 \mathrm{~V}$ in $\left[\mathrm{Os}(\mathrm{bpy})_{3}\right]^{2+12}$ to $\sim 0.2 \mathrm{~V}$ in $\left[\mathrm{Os}(\mathrm{bpy})_{2}(\mathrm{bztsc}-\mathrm{R})\right]^{+}$complexes. This large negative shift in oxidation potential observed upon replacing one bypiridine by a thiosemicarbazone ligand indicates that coordination by the thiolate sulfur of the thiosemicarbazone ligand stabilizes the trivalent state of the metals. All [M(bpy $)_{2-}$ $($ bztsc-R $)]^{+}$complexes show a second irreversible oxidation near $1.4 \mathrm{~V}$, which is tentatively assigned to the $\mathrm{M}^{\mathrm{III}}-\mathrm{M}^{\mathrm{IV}}$ oxidation [eq 2].

$\left[\mathrm{M}^{\mathrm{III}}(\mathrm{bpy})_{2}(\mathrm{bztsc}-\mathrm{R})\right]^{2+} \rightarrow\left[\mathrm{M}^{\mathrm{IV}}(\mathrm{bpy})_{2}(\mathrm{bztsc}-\mathrm{R})\right]^{3+}+\mathrm{e}^{-}$

The one-electron nature of this oxidation has been established by comparing its current height with that of the $\mathrm{M}^{\mathrm{II}}-\mathrm{M}^{\mathrm{III}}$ couple. Two successive one-electron reductions within -1.53 to -1.96 $\mathrm{V}$ are displayed by all these complexes, which are assigned to reductions of the two bpy ligands, as shown in eqs 3 and 4 . It

$\left[\mathrm{M}^{\mathrm{II}}(\mathrm{bpy})_{2}(\mathrm{bztsc}-\mathrm{R})\right]^{+}+\mathrm{e}^{-} \rightleftharpoons\left[\mathrm{M}^{\mathrm{II}}(\mathrm{bpy})\left(\mathrm{bpy}^{-}\right)(\mathrm{bztsc}-\mathrm{R})\right]$

$\left[\mathrm{M}^{\mathrm{II}}(\mathrm{bpy})\left(\mathrm{bpy}^{-}\right)(\mathrm{bztsc}-\mathrm{R})\right]+\mathrm{e}^{-} \rightleftharpoons$

$$
\left[\mathrm{M}^{\mathrm{II}}\left(\mathrm{bpy}^{-}\right)_{2}(\mathrm{bztsc}-\mathrm{R})\right]^{-}
$$

is well-known that each bpy can successively accept two electrons in the lowest unoccupied molecular orbital. ${ }^{13}$ Hence, in $\left[\mathrm{M}(\mathrm{bpy})_{2}(\mathrm{bztsc}-\mathrm{R})\right]^{+}$complexes, four successive reductions are expected. Only two of these have been experimentally observed, and the other two have not been observed because of

(11) Tokel-Takvorian, N. E.; Hemingway, R. E.; Bard, A. J. J. Am. Chem. Soc. 1973, 95, 6582 .

(12) This oxidation potential has been determined by us.

(13) (a) Vleck, A. A. Coord. Chem. Rev. 1982, 43, 39. (b) Kahl, J. L.; Hanck, K. W.; DeArmond, K. Phys. Chem. 1978, 82, 540. 

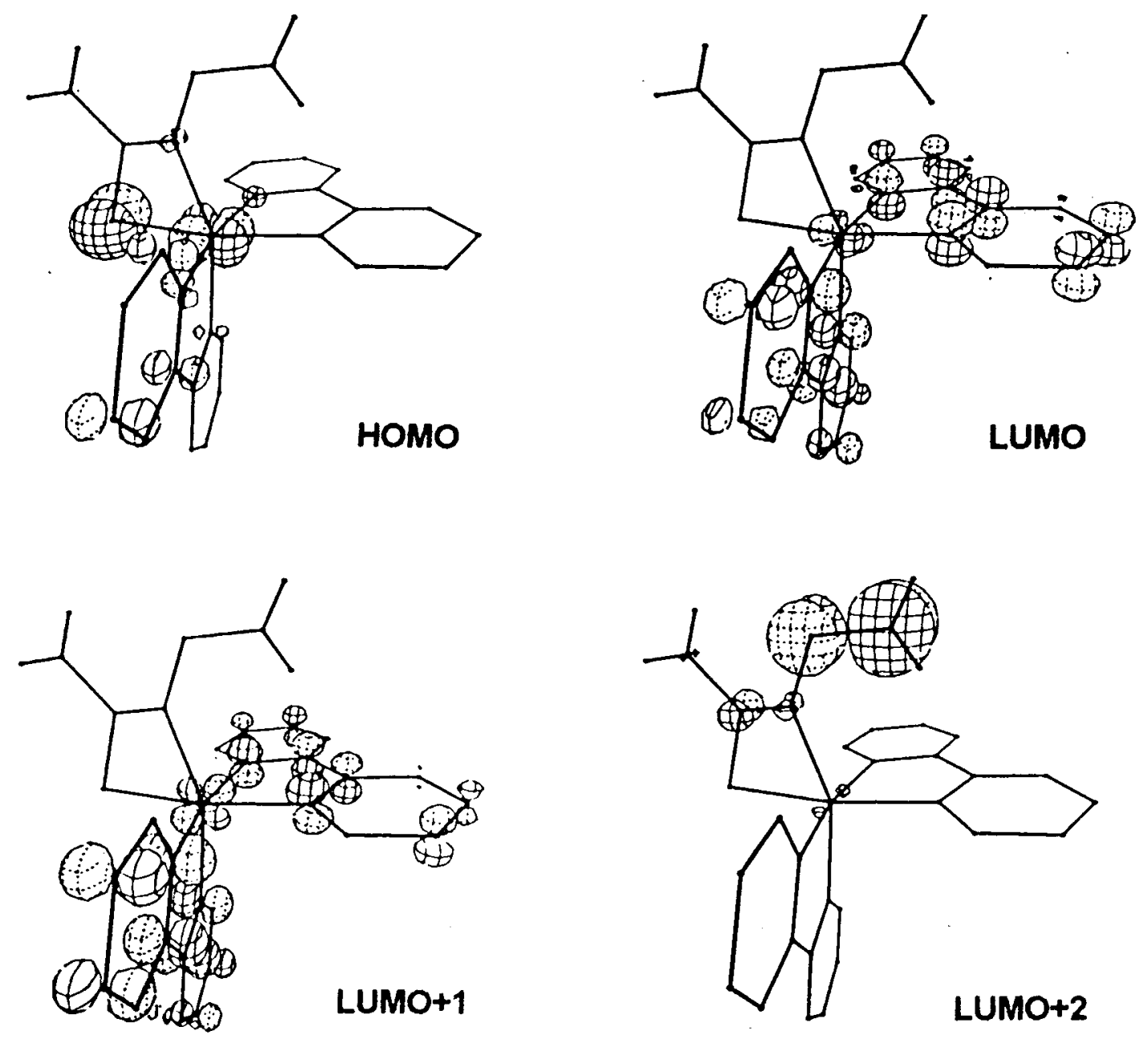

Figure 6. Molecular orbital diagram of $\left[\mathrm{Ru}(\mathrm{bpy})_{2}(\mathrm{bztsc}-\mathrm{H})\right]^{+}$complexes.

Table 4. Composition of Selected Molecular Orbitals of $\left[\mathrm{M}(\mathrm{bpy})_{2}(\mathrm{tsc})\right]^{+}$Complexes

\begin{tabular}{|c|c|c|c|c|c|c|c|}
\hline \multirow[b]{2}{*}{ compound } & \multirow{2}{*}{$\begin{array}{l}\text { contributing } \\
\text { fragments }\end{array}$} & \multicolumn{6}{|c|}{$\%$ contributions of fragments to } \\
\hline & & $\overline{\mathrm{HOMO}}-2$ & HOMO-1 & HOMO & LUMO & LUMO+1 & $\overline{\mathrm{LUMO}+2}$ \\
\hline \multirow[t]{3}{*}[\mathrm{Ru}(\mathrm{bpy})_{2}(\mathrm{bztsc}-\mathrm{H})]{$^{+}$} & $\mathrm{Ru}$ & 70 & 69 & 53 & 5 & 10 & \\
\hline & bpy & 14 & 16 & 16 & 93 & 85 & \\
\hline & bztsc $-\mathrm{H}$ & 13 & 11 & 27 & & & 97 \\
\hline \multirow[t]{3}{*}[\mathrm{Os}(\mathrm{bpy})_{2}(\mathrm{bztsc}-\mathrm{H})]{$^{+}$} & Os & 76 & 74 & 60 & 4 & 9 & \\
\hline & bpy & 13 & 14 & 13 & 94 & 87 & \\
\hline & bztsc-H & 6 & 6 & 22 & & & 98 \\
\hline \multirow[t]{3}{*}[\mathrm{Ru}(\mathrm{bpy})_{2}(\mathrm{actsc})]{$^{+}$} & $\mathrm{Ru}$ & 68 & 70 & 63 & 2 & 6 & \\
\hline & bpy & 19 & 17 & 17 & 97 & 92 & 99 \\
\hline & actsc & 11 & 10 & 16 & & & \\
\hline \multirow[t]{3}{*}[\mathrm{Os}(\mathrm{bpy})_{2}(\mathrm{actsc})]{$^{+}$} & Os & 75 & 78 & 71 & 2 & 6 & \\
\hline & bpy & 16 & 12 & 14 & 97 & 92 & 100 \\
\hline & actsc & 9 & 7 & 13 & & & \\
\hline
\end{tabular}

solvent cutoff. Cyclic voltammetric behavior of the two $\left[\mathrm{M}(\mathrm{bpy})_{2}(\mathrm{actsc})\right]^{+}$complexes are qualitatively similar to that of the $\left[\mathrm{M}(\mathrm{bpy})_{2}(\mathrm{bztsc}-\mathrm{R})\right]^{+}$complexes. However, the metalcentered oxidations take place at much lower potentials probably because of the electron-donating character of the two methyl groups of the actsc ligand.

Potentials of both $\mathrm{M}^{\mathrm{II}}-\mathrm{M}^{\mathrm{III}}$ and $\mathrm{M}^{\mathrm{III}}-\mathrm{M}^{\mathrm{IV}}$ couples in the $\left[\mathrm{M}(\mathrm{bpy})_{2}(\mathrm{bztsc}-\mathrm{R})\right]^{+}$complexes are found to be sensitive to the nature of the substituent $\mathrm{R}$ in the thiosemicarbazone ligands. The potentials increase with increasing electron-withdrawing character of $\mathrm{R}$. The plots of the oxidation potentials for both $\mathrm{M}^{\mathrm{II}}-\mathrm{M}^{\mathrm{III}}$ and $\mathrm{M}^{\mathrm{III}}-\mathrm{M}^{\mathrm{IV}}$ couples versus the Hammett substituent constant $(\sigma)$ of $\mathrm{R}^{14}$ [ $\sigma$ values of the substituents are $\mathrm{OMe}=$ $\left.-0.27, \mathrm{Me}=-0.17, \mathrm{H}=0.00, \mathrm{Cl}=0.23, \mathrm{NO}_{2}=0.78\right]$ are linear (Figure 8). The slope of these lines, which is known as the reaction constant $(\rho)^{15}$ and is a measure of the sensitivity of the oxidation potentials with $\mathrm{R}$, are respectively $0.10\left(\mathrm{M}^{\mathrm{II}}-\right.$ $\left.\mathrm{M}^{\mathrm{III}}\right)$ and $0.34\left(\mathrm{M}^{\mathrm{III}}-\mathrm{M}^{\mathrm{IV}}\right)$ for $\mathrm{M}=\mathrm{Ru}$ and $0.08\left(\mathrm{M}^{\mathrm{II}}-\mathrm{M}^{\mathrm{III}}\right)$ and $0.16\left(\mathrm{M}^{\mathrm{III}}-\mathrm{M}^{\mathrm{IV}}\right)$ for $\mathrm{M}=$ Os. This indicates that the $\mathrm{M}^{\mathrm{II}}-$ $\mathrm{M}^{\mathrm{III}}$ oxidation is less influenced by $\mathrm{R}$ than the $\mathrm{M}^{\mathrm{III}}-\mathrm{M}^{\mathrm{IV}}$ oxidation and that the sensitivity of the potentials toward $\mathrm{R}$ is more pronounced in the ruthenium complexes. It is interesting to note here that a single substituent that is eight bonds away from the electroactive metal center can influence the metalcentered redox potentials in a predictable manner.

(14) Hammett, L. P. Physical Organic Chemistry, 2nd ed.; McGraw-Hill: New York, 1970

(15) Mukherjee, R. N.; Rajan, O. A.; Chakravorty, A. Inorg. Chem. 1982, 21,785 . 
Table 5. Cyclic Voltammetric Data of the $\left[\mathrm{M}(\mathrm{bpy})_{2}(\mathrm{tsc})\right] \mathrm{ClO}_{4}$ Complexes $^{a}$

\begin{tabular}{|c|c|c|c|}
\hline compound & $\begin{array}{c}\mathrm{M}^{\mathrm{II}}-\mathrm{M}^{\mathrm{III}} \\
E_{1 / 2}, \mathrm{~V} \\
\left(\Delta E_{\mathrm{p}}, \mathrm{mV}\right)\end{array}$ & $\begin{array}{c}\mathrm{M}^{\mathrm{III}}-\mathrm{M}^{\mathrm{IV}} \\
E_{\mathrm{pa}}, \mathrm{V}\end{array}$ & $\begin{array}{c}\text { bpy reduction } \\
E_{1 / 2}, \mathrm{~V}\left(\Delta E_{\mathrm{p}}, \mathrm{mV}\right)\end{array}$ \\
\hline$\left[\mathrm{Ru}(\mathrm{bpy})_{2}(\mathrm{bztsc}-\mathrm{OMe})\right] \mathrm{ClO}_{4}$ & $0.47(60)$ & 1.23 & $-1.58(60),-1.85(60)$ \\
\hline$\left[\mathrm{Ru}(\mathrm{bpy})_{2}(\mathrm{bztsc}-\mathrm{Me})\right] \mathrm{ClO}_{4}$ & $0.48(60)$ & 1.30 & $-1.59(70),-1.87(70)$ \\
\hline$\left[\mathrm{Ru}(\mathrm{bpy})_{2}(\mathrm{bztsc}-\mathrm{H})\right] \mathrm{ClO}_{4}$ & $0.50(70)$ & 1.35 & $-1.57(80),-1.85(90)$ \\
\hline$\left[\mathrm{Ru}(\mathrm{bpy})_{2}(\mathrm{bztsc}-\mathrm{Cl})\right] \mathrm{ClO}_{4}$ & $0.52(70)$ & 1.43 & $-1.66(80),-1.91(90)$ \\
\hline$\left[\mathrm{Ru}(\mathrm{bpy})_{2}\left(\mathrm{bztsc}-\mathrm{NO}_{2}\right)\right] \mathrm{ClO}_{4}$ & $0.58(70)$ & 1.60 & $-1.75(90),-1.96(90)$ \\
\hline$\left[\mathrm{Ru}(\text { bpy })_{2}\right.$ (actsc) $] \mathrm{ClO}_{4}$ & $0.37(60)$ & 1.41 & $-1.64(90),-1.92(90)$ \\
\hline$\left[\mathrm{Os}(\mathrm{bpy})_{2}(\mathrm{bztsc}-\mathrm{OMe})\right] \mathrm{ClO}_{4}$ & $0.18(70)$ & 1.20 & $-1.55(60),-1.90(60)$ \\
\hline$\left[\mathrm{Os}(\mathrm{bpy})_{2}(\mathrm{bztsc}-\mathrm{Me})\right] \mathrm{ClO}_{4}$ & $0.19(70)$ & 1.22 & $-1.65(80),-1.92(90)$ \\
\hline$\left[\mathrm{Os}(\mathrm{bpy})_{2}(\mathrm{bztsc}-\mathrm{H})\right] \mathrm{ClO}_{4}$ & $0.20(70)$ & 1.26 & $-1.53(60),-1.82(80)$ \\
\hline$\left[\mathrm{Os}(\mathrm{bpy})_{2}(\mathrm{bztsc}-\mathrm{Cl})\right] \mathrm{ClO}_{4}$ & $0.22(70)$ & 1.30 & $-1.55(80),-1.86(90)$ \\
\hline$\left[\mathrm{Os}(\mathrm{bpy})_{2}\left(\mathrm{bztsc}-\mathrm{NO}_{2}\right)\right] \mathrm{ClO}_{4}$ & $0.26(70)$ & 1.37 & $-1.70(80),-1.93(90)$ \\
\hline$\left[\mathrm{Os}(\mathrm{bpy})_{2}(\mathrm{actsc})\right] \mathrm{ClO}_{4}$ & $0.21(60)$ & 1.11 & $-1.62(90),-1.90(90)$ \\
\hline
\end{tabular}

${ }^{a}$ Solvent, acetonotrile; supporting electrolyte, TEAP; working electrode, platinum; reference electrode, SCE; $E_{1 / 2}=0.5\left(E_{\mathrm{pa}}+E_{\mathrm{pc}}\right)$, where $E_{\mathrm{pa}}$ and $E_{\mathrm{pc}}$ are anodic and cathodic peak potentials; $\Delta E_{\mathrm{p}}=E_{\mathrm{pa}}$ $-E_{\mathrm{pc}}$; scan rate, $50 \mathrm{mV} \mathrm{s}^{-1} .{ }^{b}$ Working electrode, graphite.

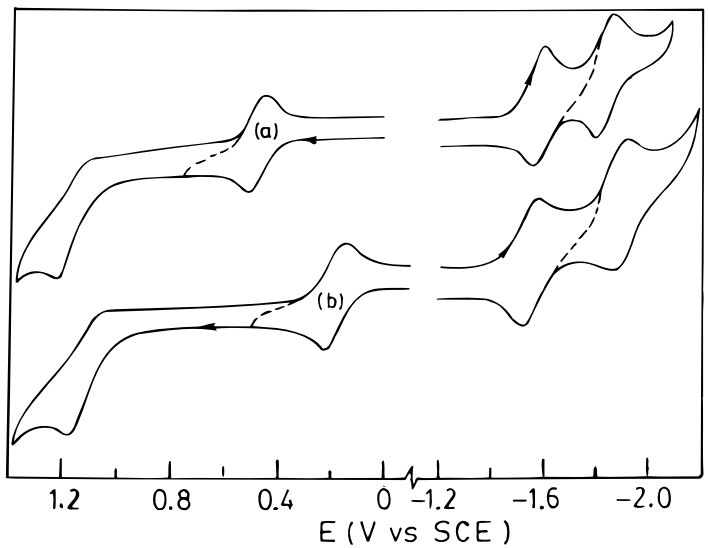

Figure 7. Cyclic voltammograms of (a) $\left[\mathrm{Ru}(\mathrm{bpy})_{2}(\mathrm{bztsc}-\mathrm{OMe})\right]^{+}$and (b) $\left[\mathrm{Os}(\mathrm{bpy})_{2}(\mathrm{bztsc}-\mathrm{OMe})\right]^{+}$in acetonitrile solution (0.1 M TEAP) at a scan rate of $50 \mathrm{mV} \mathrm{s}^{-1}$.

\section{Conclusions}

The present study reveals that the mode of coordination of thiosemicarbazone ligands (6) depends on the steric bulk of the $\mathrm{R}_{1}$ group, which is trans to the hydrazinic nitrogen. If $\mathrm{R}_{1}$ is a small group, then a stable five-membered ring (7) will be formed, and if the $\mathrm{R}_{1}$ group is large, then a four-membered ring (8) will be formed. The bulk of the $\mathrm{R}_{2}$ group, which is cis to
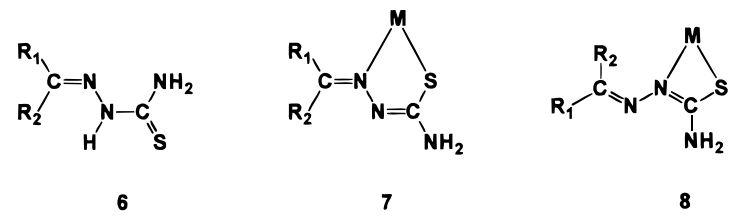

the hydrazinic nitrogen, has been observed to pose no steric constraint on the coordination mode of these ligands. Further studies of thiosemicarbazone ligands with R1 and R2 groups of different sizes are in progress.
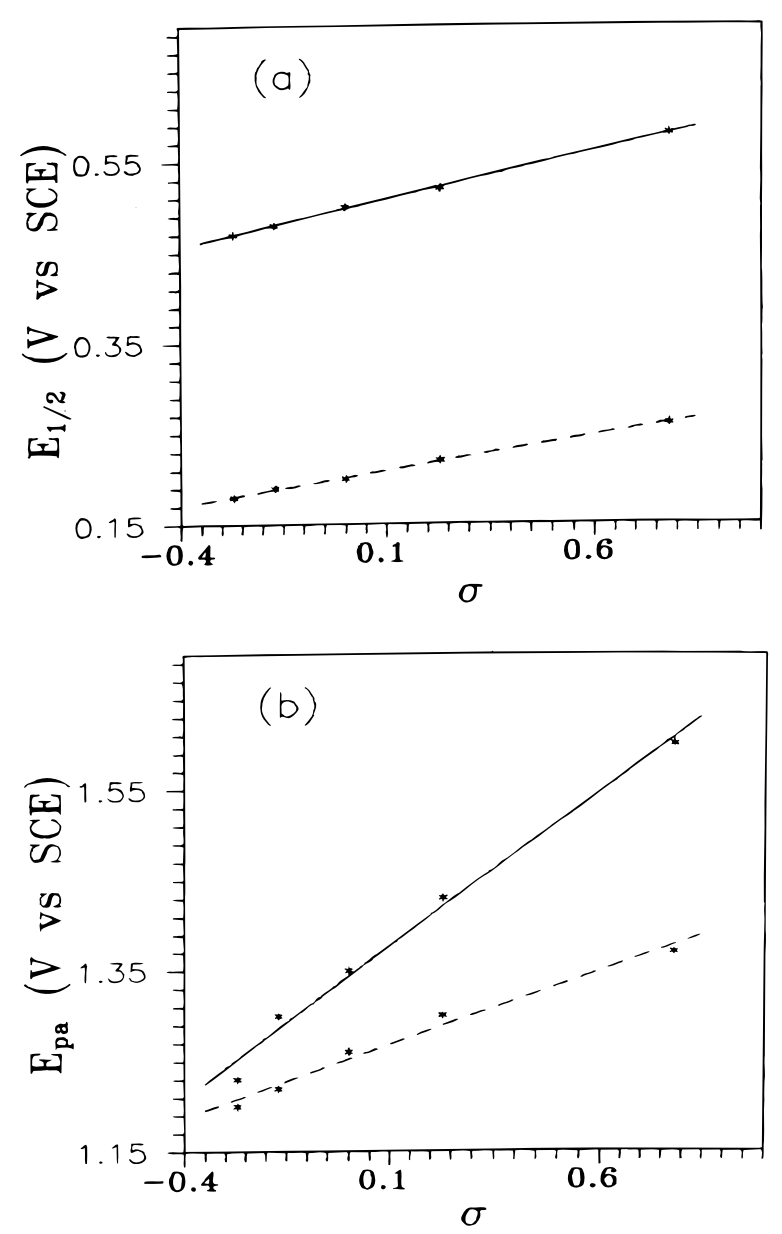

Figure 8. Least-squares plot of (a) $\mathrm{M}^{\mathrm{II}}-\mathrm{M}^{\mathrm{III}}$ oxidation potentials versus $\sigma(-$ for $\mathrm{M}=\mathrm{Ru}$ and --- for $\mathrm{M}=\mathrm{Os})$ and (b) $\mathrm{M}^{\mathrm{III}}-\mathrm{M}^{\mathrm{IV}}$ oxidation potentials versus $\sigma$ ( - for $\mathrm{M}=\mathrm{Ru}$ and - - for $\mathrm{M}=\mathrm{Os})$.

Acknowledgment. Financial assistance received from the Council of Scientific and Industrial Research, New Delhi [Grant No. 01(1408)/96/EMR-II] is gratefully acknowledged. The authors thank the Third World Academy of Sciences for financial support for the purchase of an electrochemical cell system. F.B. thanks the University Grants Commission, New Delhi, for her fellowship. Thanks are also due to Dr. Sujit Mondal, Bimal Kumar Dirghangi, and Kajal Kumar Rajak for their help in the crystal structure determination of Hbztsc-OMe, done at the Natioal Single Crystal Diffractrometer Facility, Department of Inorganic Chemistry, Indian Association for the Cultivation of Science, Calcutta.

Supporting Information Available: Tables containing crystal data and details of structure determination, atomic coordinates, anisotropic thermal parameters, and bond distances and angles for $\left[\mathrm{Ru}(\mathrm{bpy})_{2}(\mathrm{bztsc}-\right.$ $\left.\left.\mathrm{NO}_{2}\right)\right] \mathrm{ClO}_{4} \cdot \mathrm{H}_{2} \mathrm{O} \cdot 0.75 \mathrm{C}_{6} \mathrm{H}_{6}$, Hbztsc-OMe, and $\left[\mathrm{Ru}(\mathrm{bpy})_{2}(\mathrm{actsc})\right] \mathrm{ClO}_{4}$. This material is available free of charge via the Internet at http:// pubs.acs.org.

IC991083R 